\title{
GEOGRAFIA SOCIAL E TERRITÓRIOS ${ }^{1}$
}

\author{
Maria Da Graça Mouga Poças Santos ${ }^{2}$
}

A escolha deste livro, da autoria de Guy Di Méo ${ }^{4}$, para objecto de uma breve apreciação, justifica-se pela circunstância de as matérias tratadas serem de uma flagrante actualidade, numa época em que, como justamente se sublinha na Introdução, «toda a gente fala do território, a palavra está na moda».

Assumindo o intuito genérico de tratar exaustivamente o enfoque específico da Geografia Social face a esta realidade, procura-se privilegiar o próprio núcleo essencial de cada território e não tanto a demarcação dos seus limites ou fronteiras.

Propondo-se partir do conceito de espaço geográfico até alcançar a definição de território (Primeira Parte), o autor desenvolve o estudo da génese e evolução daquele, nomeadamente através das noções de espaços produzidos, percebidos, representados, vividos e sociais (Cap. 1) e interroga-se sobre a natureza do território, palavra reconhecidamente polisémica, prevalecendo-se dos contributos da etologia e das ciências sociais no respectivo estudo e sublinhando a importância da acção do tempo neste contexto (Cap. 2).

Ainda neste capítulo, registe-se que, no seguimento do enquadramento do território enquanto fenómeno psicológico e de representação social e a propósito dos factores culturais da relação territorial, é apresentado como exemplo o espaço social do bairro de Alfama, em Lisboa, indicando-se o fado como «instrumento de socialização e de territorialização» (p. 74).

Antes de se lançar na busca das estruturas elementares da territorialidade, que integra a Segunda Parte da obra, Di Méo reflecte sobre a natureza progressivamente menos materializada e mais idealizada que o conceito de território vem manifestando, sobrelevando os aspectos simbólicos.

Assim, são avançados os fundamentos humanos da territorialidade a diversas escalas: casa, cidade, região, país,... enquanto necessidade sentida de demarcar o espaço, através da sua apropriação (Cap. 3), preconizando-se vários modelos teóricos e metodológicos de identificação dos territórios, em que

1 Professora Adjunta da Escola Superior de Educação de Leiria e doutoranda em Geografia na Faculdade de Letras da Universidade de Coimbra. Rua Dr. João Soares, Porto Moniz, Apartado 3078, 2400-448 Leiria. Tel.: 2-44-829400;Fax: 2-44-829499.

2 Di MÉo, Guy (1998) - Géographie Sociale et Territoires. Paris, Éditions Nathan, 320 pp. 
assumem um particular relevo os olhares específicos da Geografia Social e da Geografia Económica que possibilitam a utilização de instrumentos ditos «de formação socio-espacial» (Cap. 4).

$\mathrm{Na}$ Terceira Parte, baseando-se nas premissas anteriormente expostas, procede-se à inventariação dos modos de construção dos territórios, nas quais surge enfatizada a dimensão geográfica na abordagem das práticas espaciais, designadamente mediante a sua representação cartográfica, considerando-se sugestivamente a paisagem como «janela aberta sobre o território» (Cap. 5).

Complementarmente, é analisado no Capítulo 6 o nível económico da territorialidade, quanto à organização espacial da produção e dos mercados, caracterizado pela sucessão de modelos de empresa (de que o fordismo constituiu um marco), os quais acarretam efeitos territoriais também diferenciados; neste ponto, deve mencionar-se que a mundialização das economias hodiernas é vista como causa de novas relações das empresas com o espaço e de novos padrões de territorialização dos sistemas produtivos.

Finalmente, surge-nos a dimensão ideológica e cultural da territorialidade (Cap. 7), fortemente ligada à relação entre poder e espaço (Cap. 8), em que se dissecam os modos como são criadas as imagens territoriais, enquanto mecanismos identitários ou até como símbolos de verdadeiras ideologias territoriais. É aqui que Di Méo enuncia o que considera uma «Geografia das formas elementares do poder», que se traduzirá pela identificação de cada fórmula de poder com uma dada configuração espacial e onde avultam os processos de dominação do/no espaço de que é arquétipo o território político do Estado-Nação, hoje em dia algo fragilizado pela emergência ou redescoberta de novas territorialidades geográficas (cidades, áreas metropolitanas, etc.).

Em conclusão geral, esta obra de elevada densidade conceptual e de grande rigor científico, afasta-se tanto de uma visão politológica, como da perspectiva naturalista, uma e outra redutoras, apontando para uma noção de território vista essencialmente como uma construção social, cuja singularidade em cada caso concreto resulta de «um acordo tácito intervindo a um nível de escala particular do espaço geográfico» (p. 276). 